\title{
Band alignment at the BaCuSeF/ZnTe interface
}

Cite as: Appl. Phys. Lett. 96, 162110 (2010); https://doi.org/10.1063/1.3405757

Submitted: 08 March 2010 • Accepted: 01 April 2010 • Published Online: 22 April 2010

Andriy Zakutayev, Janet Tate, Heather A. S. Platt, et al.

\section{ARTICLES YOU MAY BE INTERESTED IN}

Electronic properties of BaCuChF (Ch=S,Se,Te) surfaces and BaCuSeF/ZnPc interfaces

Journal of Applied Physics 107, 103713 (2010); https://doi.org/10.1063/1.3380594

Valence band structure of BaCuSF and BaCuSeF

Journal of Applied Physics 100, 083705 (2006); https://doi.org/10.1063/1.2358828

Band-structure, optical properties, and defect physics of the photovoltaic semiconductor SnS

Applied Physics Letters 100, 032104 (2012); https://doi.org/10.1063/1.3675880

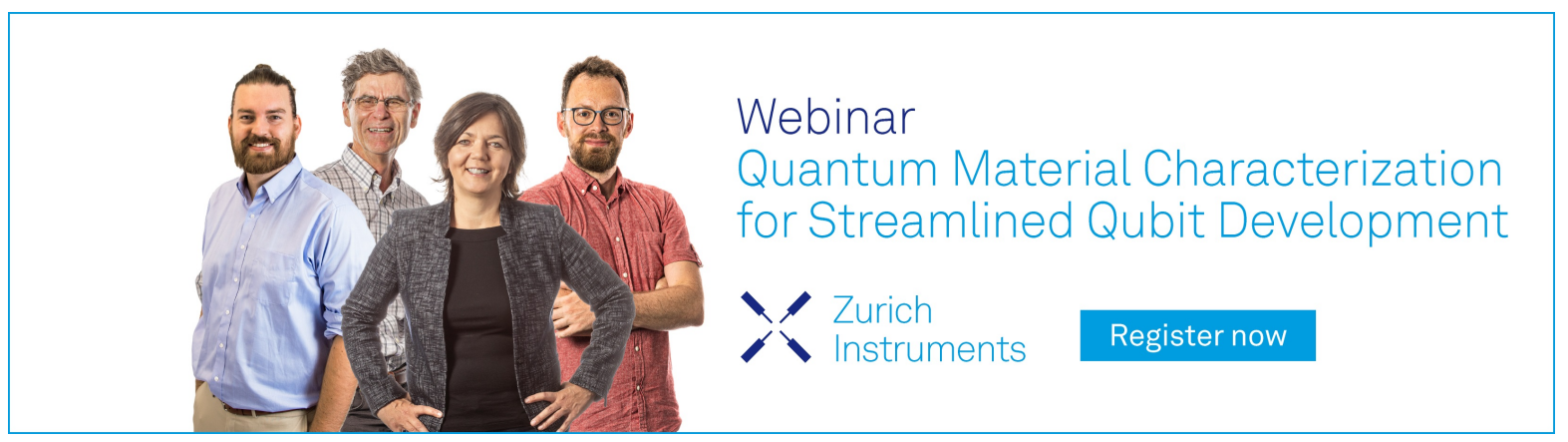




\section{Band alignment at the BaCuSeF/ZnTe interface}

Andriy Zakutayev, ${ }^{1}$ Janet Tate, ${ }^{1, a)}$ Heather A. S. Platt, ${ }^{2}$ Douglas A. Keszler, ${ }^{2}$

Alireza Barati, ${ }^{3}$ Andreas Klein, ${ }^{3}$ and Wolfram Jaegermann ${ }^{3}$

${ }^{1}$ Department of Physics, Oregon State University, Corvallis, Oregon 97331-6507, USA

${ }_{2}^{2}$ Department of Chemistry, Oregon State University, Corvallis, Oregon 97331-4003, USA

${ }^{3}$ Department of Materials and Earth Sciences, Darmstadt University of Technology,

Darmstadt 64287, Germany

(Received 8 March 2010; accepted 1 April 2010; published online 22 April 2010)

In situ photoemission spectroscopy experiments are used to characterize the interface between ZnTe and the wide band gap $p$-type semiconductor $\mathrm{BaCuSeF}$. The contact is characterized by a null valence-band offset, a large conduction-band offset, and a chemically graded interface. By applying the transitivity rule for band offset and on the basis of similarities in chemical composition, $\mathrm{BaCuSeF}$ contact to chalcogenide photovoltaic absorber materials would be expected to have similar properties. By extension, $\mathrm{BaCuChF}(\mathrm{Ch}=\mathrm{S}, \mathrm{Se}, \mathrm{Te})$ materials are suitable as $p$-layers in $p$-i-n double-heterojunction solar cells fabricated with $\mathrm{CdTe}, \mathrm{Cu}(\mathrm{InGa}) \mathrm{Se}_{2}$, and $\mathrm{Cu}_{2} \mathrm{ZnSnS}_{4}$ absorbers. (C) 2010 American Institute of Physics. [doi:10.1063/1.3405757]

One of the contemporary challenges of applied physics is the advancement of photovoltaic (PV) technologies. For example, development of $p$-type windows for $p$ - $i-n$ chalcogenide solar cells is currently needed to improve efficiencies. An ideal $p$-window layer would have (i) a high concentration of free holes for higher conductivity, (ii) a band gap wider than the absorber, $i$-layer, (iii) a small valence-band (VB) offset relative to the absorber for facile hole extraction, (iv) a large conduction band (CB) offset relative to the absorber to reflect electrons, and $(\mathrm{v})$ a chemically graded interface to limit the formation of interfacial states. ${ }^{1} \mathrm{ZnTe}$ is one studied $p$-window material in CdTe solar cells. ${ }^{2,3} \mathrm{Cu}$ and $\mathrm{Cu}_{x} \mathrm{Te}_{y}$ also form Ohmic contacts to CdTe but their band alignments are not ideal. ${ }^{4,5}$

Here we propose using chalcogen-based transparent conductors, ${ }^{6}$ such as $\mathrm{BaCuChF}(\mathrm{Ch}=\mathrm{S}, \mathrm{Se}, \mathrm{Te})$ (Refs. 7 and 8) for anode applications in chalcogenide $p-i-n$ PV devices. These materials have high concentrations of free holes $\left(10^{18}-10^{20} \mathrm{~cm}^{-3}\right.$ ) (Refs. 9 and 10) and tunable ${ }^{10,11}$ wide $^{12}$ optical band gaps $(2.9-3.5 \mathrm{eV})$. $\mathrm{BaCuChF}$ are likely to form graded interfaces with the chalcogenide absorbers since these materials contain chalcogen atoms. However, to date, the band alignment of $\mathrm{BaCuChF}$ with inorganic compounds has not been studied. In this paper, we report X-ray- and ultraviolet-photoemission spectroscopy results (XPS/UPS) for $\mathrm{BaCuSeF} / \mathrm{ZnTe}$ interfaces, and discuss possible applications of $\mathrm{BaCuChF}$ in chalcogenide solar cells based on $\mathrm{CdTe}$, $\mathrm{Cu}(\mathrm{InGa}) \mathrm{Se}_{2}$ (CIGS), and $\mathrm{Cu}_{2} \mathrm{ZnSnS}_{4}$ (CZTS) absorbers.

$\mathrm{BaCuSeF}$ thin films $(200 \mathrm{~nm})$ were prepared by pulsed laser deposition from stoichiometric $\mathrm{BaCuSeF}$ targets on $\mathrm{Si}$ (001) and amorphous $\mathrm{SiO}_{2}$ substrates. $\mathrm{BaCuSeF}$ films were polycrystalline, single phase, $p$-type, and on average $75 \%$ transparent over the wavelength range 400-2500 $\mathrm{nm}$. The transparency is partly limited by the reflective losses $(\sim 15 \%)$ at the front surface. Bulk and surface compositions of the thin films were determined by electron probe microanalysis and XPS, respectively. $\mathrm{BaCuSeF}$ thin films were capped with $1000 \mathrm{~nm}$ of amorphous Se for protection ${ }^{13}$

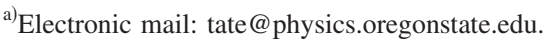

during transportation from Corvallis, OR to Darmstadt, Germany. This protection was necessary, since uncapped $\mathrm{BaCuChF}$ surfaces were oxidized and contaminated, ${ }^{14}$ which could have been a contributing reason for the poor performance of $\mathrm{BaCuTeF}$ in PV devices reported before. ${ }^{15}$ For the in situ interfacing experiments, $280 \mathrm{~nm}$ thick ZnTe layers were sequentially deposited on the $\mathrm{BaCuSeF}$ film at room temperature in a stepwise manner, and XPS/UPS were recorded after each step using the DAISY-SOL. ${ }^{16}$ Details of these and similar experiments appear elsewhere. ${ }^{14}$

The XPS and UPS spectra of the $\mathrm{BaCuSeF} / \mathrm{ZnTe}$ interface are shown in Fig. 1. For a thick ZnTe layer $(>25 \AA)$, $\mathrm{BaCuSeF}$ and ZnTe XPS peaks shift to higher binding energies (BE) with increasing ZnTe thickness, indicating downward $\mathrm{VB}$ bending of $\mathrm{BaCuSeF}$ caused by electron transfer to this material. The $\mathrm{BE}$ of the secondary electron edge changes for low ZnTe thickness $(<25 \AA)$, indicating the change of
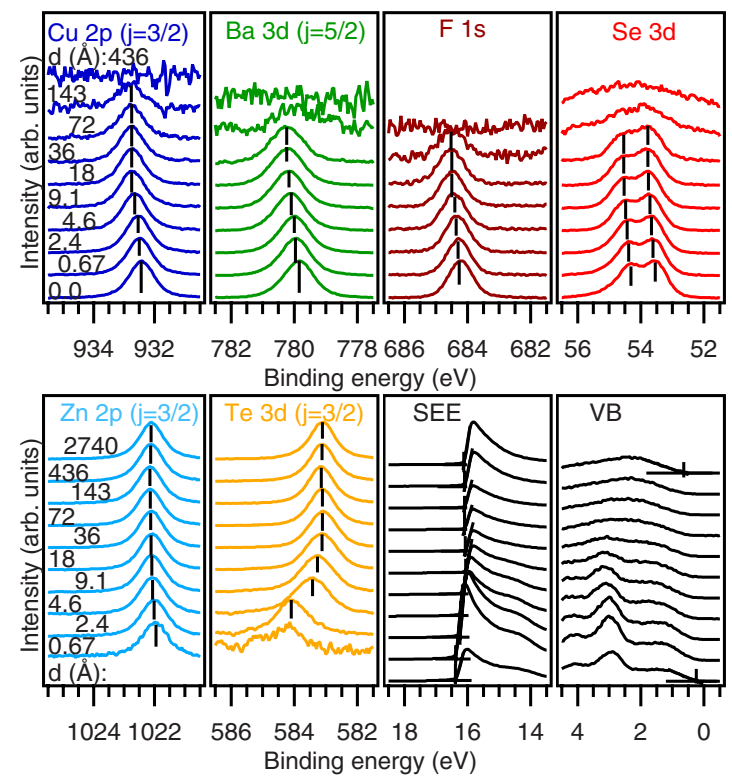

FIG. 1. (Color online) Normalized photoemission spectra of the $\mathrm{BaCuSeF} /$ $\mathrm{ZnTe}$ interface. ZnTe thicknesses $d$ are the same for all panels in a row. The vertical lines indicate binding energies used to plot Fig. 2. 

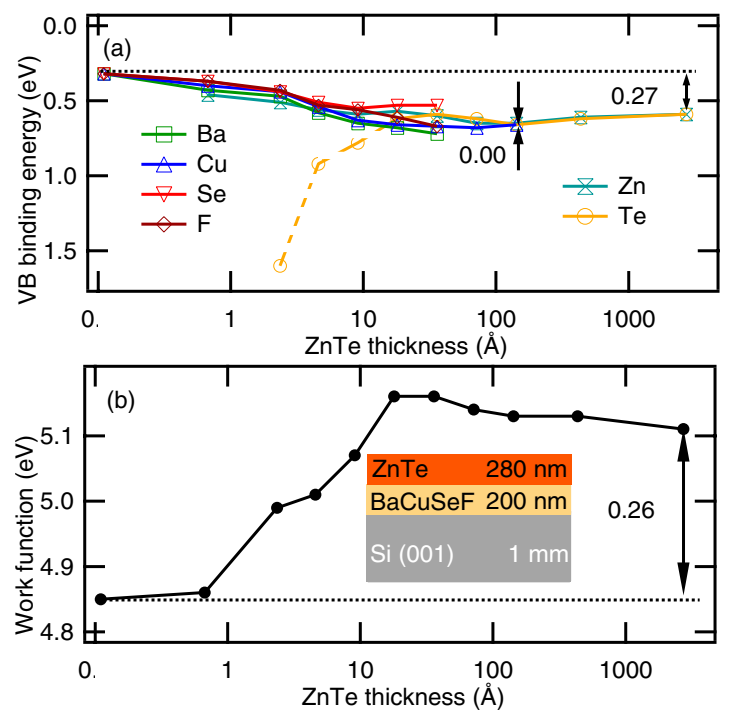

FIG. 2. (Color online) (a) Binding energy of the BaCuSeF and $\mathrm{ZnTe}$ valence bands calculated from XPS core-level spectra. The dashed line represents the shift in $\mathrm{Te} 3 d_{3 / 2}$ states due to charge transfer from Te atoms. (b) Work function of the $\mathrm{BaCuSeF} / \mathrm{ZnTe}$ interface. The final configuration of the sample is schematically depicted in the inset.

the work function (WF) due to change in an interface dipole. In this thickness range, the Te $3 d_{3 / 2}$ and the $\mathrm{Zn} 2 p_{3 / 2}$ XPS peaks do not shift in parallel. We attribute a strong shift in the Te $3 d_{3 / 2}$ line at low coverage to the transfer of electrons from $\mathrm{Te}$ atoms. The $\mathrm{Zn} 2 p_{3 / 2}$ peak does not show this charge-transfer shift, because $\mathrm{Zn}$ atoms do not contribute to the VB of ZnTe. Similar effect has been observed at the $\mathrm{BaCuSeF} / \mathrm{ZnPc}$ interface. ${ }^{14}$

There is interdiffusion at the $\mathrm{BaCuSeF} / \mathrm{ZnTe}$ interface. In Fig. 1, the $\mathrm{Cu} 2 p_{3 / 2}$ XPS peak is present at $143 \AA \mathrm{ZnTe}$ coverage, whereas the $\mathrm{Ba} 3 d_{5 / 2}$ and $\mathrm{F} 1 s$ peaks that have lower BE are absent. The bulk of ZnTe films is Te-poor by 4 at. $\%$ but the surfaces are Te-rich by 20 at. \%, so it is likely that $\mathrm{Cu}$ atoms diffuse into $\mathrm{ZnTe}$ and form $\mathrm{Cu}-\mathrm{Zn}-\mathrm{Te}$ or $\mathrm{Cu}-\mathrm{Te}$ phases. The interdiffusion layer has been confirmed using high-resolution STEM/EDX measurements that will be published elsewhere. Similar effect was also observed at the $\mathrm{CdTe}$ interfaces with other $\mathrm{Cu}$-containing back contacts. ${ }^{4,5}$

$\mathrm{BaCuSeF}$ and $\mathrm{ZnTe} \mathrm{VB} \mathrm{BE}$ and the WF as a function of $\mathrm{ZnTe}$ thickness are shown in Fig. 2. Decapped BaCuSeF surface has a VB BE of $0.32 \pm 0.10 \mathrm{eV}$, larger than for the thin film bulk deduced from measured carrier concentration and calculated density of states $(-0.04 \mathrm{eV})$. The WF is $4.85 \pm 0.05 \mathrm{eV}$, larger than for the pressed pellets measured by UPS $(3.6 \mathrm{eV}){ }^{17}$ A thick ZnTe layer $(280 \mathrm{~nm})$ has a VB $\mathrm{BE}$ of $0.59 \pm 0.10 \mathrm{eV}$ and a WF of $5.11 \pm 0.05 \mathrm{eV}$.

Measured VB BEs and the WFs (Fig. 2) were used to establish band alignment of $\mathrm{BaCuSeF}$ and $\mathrm{ZnTe}$ before contact [Fig. 3(a)]. After contact, $\mathrm{BaCuSeF}$ and $\mathrm{ZnTe}$ have the same VB BE [Fig. 2(a)], so the VB offset is $0.00 \pm 0.10 \mathrm{eV}$ [Fig. 3(b)]. The CB offset is $0.94 \pm 0.10 \mathrm{eV}$, as calculated from the $\mathrm{BaCuSeF}$ (Ref. 12) and ZnTe (Ref. 18) band gaps [Fig. 3(c)]. The band bending of $0.27 \mathrm{eV}$ [Fig. 2(a)] and the change of the WF of $0.26 \mathrm{eV}$ [Fig. 2(b)] sum to a vacuum level shift in $0.53 \pm 0.10 \mathrm{eV}$ [Fig. 3(b)]. The higher vacuum level in $\mathrm{ZnTe}$ would correspond to an interface dipole with the negative end toward $\mathrm{ZnTe}$. This direction is contraindicated by the direction of the $\mathrm{BaCuSeF}$ band bending and by the high binding energy of the $\mathrm{Te} 3 d_{3 / 2}$ line at low coverage

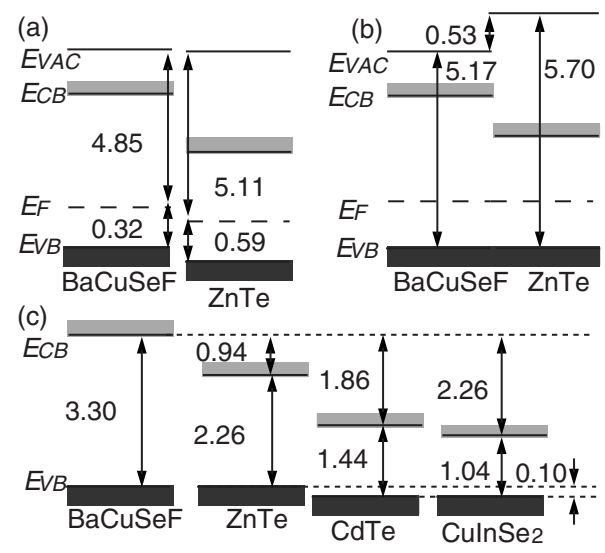

FIG. 3. Alignment of the energy levels of BaCuSeF and $\mathrm{ZnTe}$ (a) before and (b) after contact as measured by PES. (c) Band offsets of $\mathrm{BaCuSeF}$ with CdTe and $\mathrm{CuInSe}_{2}$ calculated from the literature values of the band offsets of these materials with ZnTe. All energies are in electron volt.

[Fig. 2(a)], which both point to an opposite direction of the charge transfer. Possible reasons for the opposite direction of the charge transfer are the graded character of the interface or a large surface dipole contribution to the work function of decapped $\mathrm{BaCuSeF}$, which is modified during interface formation. The latter is likely, as the measured ionization potential $\left(E_{\mathrm{VAC}}-E_{\mathrm{VB}}\right)$ of $\mathrm{BaCuSeF}(5.17 \pm 0.15 \mathrm{eV})$ is much smaller, e.g., than that of $\mathrm{CuInSe}_{2}(6.1 \mathrm{eV}),{ }^{19}$ which has a similar VB structure.

The band alignment of $\mathrm{BaCuSeF}$ with the chalcogenide PV materials is shown in Fig. 3(c). It was calculated from the $\mathrm{ZnTe} / \mathrm{CdTe}$ and $\mathrm{CdTe} / \mathrm{CuInSe}_{2}$ band offsets using the transitivity rule. ${ }^{20,21} \mathrm{BaCuSeF} / \mathrm{CdTe}$ and $\mathrm{BaCuSeF} / \mathrm{CuInSe}{ }_{2}$ interfaces have $\mathrm{VB}$ offsets of $0.10 \pm 0.10 \mathrm{eV}$, and $\mathrm{CB}$ offsets of $1.86 \pm 0.10 \mathrm{eV}$ and $2.26 \pm 0.10 \mathrm{eV}$, respectively. The small VB offsets are expected, because the $\mathrm{Se} 4 p-\mathrm{Cu} 3 d$ repulsion in $\mathrm{BaCuSeF}$ is stronger than the $\mathrm{Te} 5 p$ - $\mathrm{Cd} 4 d$ repulsion in $\mathrm{CdTe}$, and the $\mathrm{VB}$ character of $\mathrm{BaCuSeF}$ is similar to that of CuInSe $2 .{ }^{17}$ The VB character of $\mathrm{Cu}_{2} \mathrm{ZnSnS}_{4}$ is more similar to $\mathrm{BaCuSF}$ than $\mathrm{BaCuSeF}$, so the two sulfides constitute a good match for CZTS solar cells. ${ }^{22} \mathrm{BaCuChF}$ interfaces with $\mathrm{ZnTe}, \mathrm{CdTe}, \mathrm{CuInSe}{ }_{2}$, and $\mathrm{Cu}_{2} \mathrm{ZnSnS}_{4}$ are likely to have similar interdiffusion because of the similar chemical compositions of II-VI, (I-III)-VI ${ }_{2}$, and ( $\left.\mathrm{I}_{2}-[\mathrm{II}-\mathrm{IV}]\right)-\mathrm{VI}_{4}$ semiconductors.

Overall, $\mathrm{BaCuChF}$ materials with appropriate surface protection or fully in situ processing should make good $p$-type contacts in chalcogenide $p-i-n$ solar cells. In addition, $\mathrm{BaCuSeF}$ has the potential to replace the $\mathrm{Cu}$ or $\mathrm{Cu}_{2-x} \mathrm{Te}$ back contact in CdTe PV devices, due to its better band alignment with $\mathrm{CdTe}$. Finally, $\mathrm{BaCuChF}$ are transparent enough to be used in tandem chalcogenide solar cells. Related $\mathrm{LaCuOCh}$ materials ${ }^{23,24}$ are also promising for these applications, since the $\mathrm{VB}$ characters of $\mathrm{BaCuChF}$ and $\mathrm{LaCuOCh}$ are similar. ${ }^{17}$

In summary, we have measured the VB offset between $\mathrm{BaCuSeF}$ and $\mathrm{ZnTe}$ by XPS/UPS. There is no measurable VB discontinuity and the interface is graded, which makes $\mathrm{BaCuSeF}$ an ideal $p$-type contact to ZnTe. A small VB offset and a similar chemistry of $\mathrm{ZnTe}, \mathrm{CdTe}$, and $\mathrm{CuInSe}_{2}$ suggest that $\mathrm{BaCuSeF}$ is likely to make a good $p$-layer for the chalcogenide $p-i-n$ solar cells.

This work was supported by the German Research Foundation (Deutsche Forschungsgemeinschaft) through the Cen- 
ter of Excellence 595 (Sonderforschungsbereich 595) and the U.S. National Science Foundation under Grant No. DMR0804916.

${ }^{1}$ W. Jaegermann, A. Klein, and T. Mayer, Adv. Mater. 21, 4196 (2009). ${ }^{2}$ B. Späth, J. Fritsche, A. Klein, and W. Jaegermann, Appl. Phys. Lett. 90, 062112 (2007).

${ }^{3}$ A. Barati, A. Klein, and W. Jaegermann, Thin Solid Films 517, 2149 (2009).

${ }^{4}$ B. Späth, K. Lakus-Wollny, J. Fritsche, C. S. Ferekides, A. Klein, and W. Jaegermann, Thin Solid Films 515, 6172 (2007).

${ }^{5}$ G. Teeter, J. Appl. Phys. 102, 034504 (2007).

${ }^{6}$ J. Tate, P. F. Newhouse, R. Kykyneshi, P. A. Hersh, J. Kinney, D. H. McIntyre, and D. A. Keszler, Thin Solid Films 516, 5795 (2008).

${ }^{7}$ H. Yanagi, J. Tate, S. Park, C.-H. Park, and D. A. Keszler, Appl. Phys. Lett. 82, 2814 (2003).

${ }^{8}$ C.-H. Park, R. Kykyneshi, A. Yokochi, J. Tate, and D. A. Keszler, J. Solid State Chem. 180, 1672 (2007).

${ }^{9}$ R. Kykyneshi, D. H. McIntyre, J. Tate, C.-H. Park, and D. A. Keszler, Solid State Sci. 10, 921 (2008).

${ }^{10}$ C.-H. Park, D. A. Keszler, H. Yanagi, and J. Tate, Thin Solid Films 445, 288 (2003).

${ }^{11}$ A. Zakutayev, D. H. McIntyre, G. Schneider, D. A. Keszler, C.-H. Park, and J. Tate, "Tunable properties of wide-bandgap $p$-type $\mathrm{BaCu}\left(\mathrm{Ch}_{1-x} \mathrm{Ch}_{x}^{\prime}\right) \mathrm{F}(\mathrm{Ch}=\mathrm{S}, \mathrm{Se}, \mathrm{Te})$ thin film solid solutions" (to be published).
${ }^{12}$ A. Zakutayev, R. Kykyneshi, G. Schneider, D. H. McIntyre, and J. Tate, Phys. Rev. B 81, 155103 (2010).

${ }^{13}$ T. Schulmeyer, R. Hunger, A. Klein, W. Jaegermann, and S. Niki, Appl. Phys. Lett. 84, 3067 (2004).

${ }^{14}$ A. Zakutayev, J. Tate, H. A. S. Platt, D. A. Keszler, C. Hein, T. Mayer, A. Klein, and W. Jaegermann, "Electronic properties of $\mathrm{BaCuChF}(\mathrm{Ch}=\mathrm{S}$, $\mathrm{Se}, \mathrm{Te}$ ) surfaces and BaCuSeF/ZnPc interfaces," J. Appl. Phys. (to be published)

${ }^{15}$ J. A. Spies, R. Schafer, J. F. Wager, P. Hersh, H. A. S. Platt, D. A. Keszler, G. Schneider, R. Kykyneshi, J. Tate, X. Liu, A. D. Compaan, and W. N. Shafarman, Sol. Energy Mater. Sol. Cells 93, 1296 (2009).

${ }^{16}$ J. Fritsche, A. Klein, and W. Jaegermann, Adv. Eng. Mater. 7, 914 (2005)

${ }^{17}$ H. Yanagi, J. Tate, S. Park, C.-H. Park, D. A. Keszler, M. Hirano, and H. Hosono, J. Appl. Phys. 100, 083705 (2006).

${ }^{18}$ S. J. Fonash, Solar Cell Device Physics (Academic, New York, 1981).

${ }^{19}$ T. Schulmeyer, Ph.D. thesis, Technische Universität Darmstadt, 2005.

${ }^{20}$ T. Schulmeyer, R. Hunger, M. Lebedev, W. Jaegermann, A. Klein, R. Kniese, and M. Powalla, Thin Solid Films 480-481, 110 (2005).

${ }^{21} \mathrm{~K}$. Ellmer, A. Klein, and B. Rech, Transparent Conductive Zinc Oxide (Springer, New York, 2008).

${ }^{22}$ J. Paier, R. Asahi, A. Nagoya, and G. Kresse, Phys. Rev. B 79, 115126 (2009).

${ }^{23}$ K. Ueda, S. Inoue, S. Hirose, H. Kawazoe, and H. Hosono, Appl. Phys. Lett. 77, 2701 (2000).

${ }^{24}$ H. Hiramatsu, K. Ueda, H. Ohta, M. Hirano, T. Kamiya, and H. Hosono, Appl. Phys. Lett. 82, 1048 (2003).

This article may be downloaded for personal use only. Any other use requires prior permission of the author and AIP Publishing. This article appeared in (Appl. Phys. Lett. 96, 162110 (2010)) and may be found at (https://doi.org/10.1063/1.3405757).

Available under only the rights of use according to UrhG. 